\title{
President Farmajo's Election: A Brief Hiatus or Hype in Ethiopia's Regional Hegemonic Ambition
}

\author{
Ali [Sheikh] Ahmed ABDI ${ }^{1}$
}

\begin{abstract}
The paper aims to identify the existing state of affairs and relationships between Somalia and Ethiopia in the era of President Mohamed Abdullahi Farmajo, and the multiplicity of other states (Middle East and Turkey) with vested interests in Somalia that might radicalize diplomatic relations following the 2017 election. Rival foreign countries present in the Horn of Africa that sought hegemonic dominance, including the USA, China, Turkey, Russia, and the Middle East, watched the political changes that took place in Somalia after the election of President Mohamed Abdullahi Farmajo. However, upon taking the presidential oath, Farmajo's leadership and foreign policy turned towards Turkey and Qatar as an alternative power to lean against in the event of pursuing his irredentist ambitions as was constantly outlined in his rhetorical speech before the election is now on the making. Nevertheless, the revolving question is, would it cause a brief hiatus or hype in Ethiopia's regional hegemonic ambition?
\end{abstract}

Keywords: Ethiopia, Somalia, Election, Rhetoric, Relation and Hegemony

\section{Introduction}

The socio-political and economic ties between the peoples of Somalia and Ethiopia stretch back to antiquity, and perhaps to a point of common origin. Yet the two countries have experienced centuries of transmissible conflict and violence that have blemished their international, as well as intranational relationships. Since the collapse of Siad Barre's military rule in Somalia in 1991, the nature of Ethiopia-Somalia relations has been asymmetrical, where the balance of power weighed in Ethiopia's favour inevitably resulting in a neo-hegemony that dominated the Horn region until 2017, when former Prime Minister Mohamed Abdullahi, alias "Farmajo", became the sixth president of post-1991 Somalia. President Farmajo was not Addis Ababa's preferred candidate during the Somali presidential campaign in 2017. Instead, the Ethiopian Government supported the previous head of state, Hassan Sheikh Mohamud. A widely-held hypothesis was that the new Somali president would question the hegemonic role which Ethiopia has played in the Horn region since 1991, given the country's informal and formal military presence in Somalia. Yet the desperation of Mogadishu's security issues was a concern that would leave Farmajo's government with little motivation to disavow Ethiopia. Sine qua non that reversed President

Ph.D. student pursuing Security Studies under the Doctoral School of Military Science at the National University of Public Service; e-mail: Dhagaweyne3@gmail.com; ORCID: 0000-0002-0667-3957 
A. [S.] Ahmed ABDI: President Farmajo’s Election: A Brief Hiatus or Hype in Ethiopia’s Regional...

Farmajor's pugnacious anti-Ethiopia campaign rhetoric - a fact that faltered now and lose strength or momentum to any further extent or to listen any more.

At the onset, the six regional state administrations under the Federal Government of Somalia, governed by strongmen, have developed over time and are perceived locally as more imperative and dominant than preceding Somalia Presidents. All of them seemed to prefer other candidates to Farmajo. For example, Ahmed Madobe, the President of the Jubaland Regional State favoured Sharif Sheikh Ahmed, his long-term friend from the days when the Islamic Courts Union reached its peak. Abdiweli Ali Gaas from Puntland arrived in the week prior to the presidential election race in Mogadishu with the intention of sponsoring the then sitting Prime Minister Omar Abdirashid Ali Sharmarke, his own kin. It is difficult to ascertain what lay behind this unholy alliance formed at the eleventh hour between both candidates of the 2017 Somalia presidential race. However, speculation appearing in public discourse hinted that President Abdiweli Gaas' withdrawal from the race to support Sharmarke's campaign came about through an infusion of substantially unrestricted funds. President Sharif Hassan Sheik Aden of the South-West Regional Administration affirmed his steady support behind the then sitting President of the Federal Government of Somalia Hassan Sheik Mohamud, owing to an Ethiopia-driven compromise. One would contend that Sharif Hassan's choice to help Hassan Sheikh Mohamud came after he was booted out of the race in the 4.5 voting framework. The 4.5 equation is a clan-quota power-sharing recipe created as a device for political settlement and compromise among the Somalis in Somalia. Still far expelled from the rule of one individual, one vote system, Somalian citizen voters may not have soon the chance to witness the universal suffrage-the right of almost all adults to vote in political elections. President Ali Osoble of Hirshabelle Regional State was irresolute, whether to lend his support to either Hassan Sheik Mohamud or Sharmarke. [1]

The only avenue available for any Somali politician to unite public support in his or her favour was to evoke pan-Somali irredentism, the enduring dynamics of which marred the Ethiopia-Somalia relations at the beginning of the $20^{\text {th }}$ century owing to the blended involvement of cross-continental and regional actors. The legacy of European and Ethiopian imperialist invasions resulted in the partition of Somali individuals into four Horn of Africa countries, namely Somalia (including North and South territories), Ethiopia, Kenya and Djibouti.

The first phase of Somali household divisions emanated from the era of colonisation, which was marked by rapid colonial expansion of the major European powers and Ethiopia that occurred between 1875 to 1912. The major players of this exploration and conquest of the Somali hinterlands were Great Britain, France, Ethiopia, and to a lesser extent Italy, which later took the southern part of Somalia. [2] The colonial borderlines penetrated deeply into the social structures of the societies in the Horn and cut across ethnic, etymological, ancestral and, in some cases, national boundaries. Western historiographers and African elites alike perceived these boundaries as hallowed even though they laid the foundation for many contemporary African border disputes, conflict and consequent suffering.

Meanwhile, the post-frontier elites had a tendency to force a level of sacredness on these delineated border limits by exercising genuine control of the border fringe zones or exerting influence [3] as in the case of Ogaden and Northern Frontier Districts of Ethiopia and Kenya respectively. Thus, pan-Somali nationalism that promoted irredentism led to two major Ethiopian-Somali wars in the $20^{\text {th }}$ century. The first war took place in 1963-1964 and the 
most damaging conflict occurred in 1977-1978 over the Ogaden region. The two countries succumbed to the agreement of restoring diplomatic relations only relatively recently in 1988. [4] The second major event that defined the status of Ethiopian-Somali diplomatic relations in the $20^{\text {th }}$ century was the Cold War and the proxy struggle of superpowers in the Horn of Africa region, owing to its strategic geopolitical position. But again, the geopolitical watershed of the Horn exerted considerable influence on the alignment of ideologies as well as the internal political dynamics defining the relationship between Ethiopia and Somalia.

Consequently, this paper aims to identify the existing state of affairs and relationships between Somalia and Ethiopia in the era of President Mohamed Abdullahi Farmajo, and the multiplicity of other states (Middle East and Turkey) with vested interests in Somalia that might radicalise diplomatic relations following the 2017 election. Rival foreign countries present in the Horn of Africa that sought hegemonic dominance, including the USA, China, Turkey, Russia, and the Middle East, watched the political changes that took place in Somalia after the election of President Mohamed Abdullahi Farmajo. Most of them, using the analysis of the political annals in the Horn region, as well as President Farmajo's variable debate speeches, assumed that his leadership would soon worsen the Ethiopian-Somali relations. However, upon taking the presidential oath, Farmajo's leadership and foreign policy turned towards Turkey and Middle East countries as alternative powers to lean against in the event of pursuing his irredentist ambitions as was constantly outlined in his rhetorical speech before the election. Nevertheless, the final candidates' debate at the polling house was a defining moment. Farmajo, who mastered the art of Somali nationalist psyche delivered a speech loaded with strong messages lashing out against foreign interference into Somalia's affairs. He also expressed such a strong Somali irredentist opinion that spread like bushfire across the Somali populace. On top of that, the Diaspora media profiled his pan-Somali campaign agendas. Likewise, leading religious clerics gave their systematic blessing to pan-Somali nationalism in their Khutba ${ }^{2}$ at the polling hall, which was believed to have indoctrinated the youthful Electoral College voters in the Federal Republic of Somalia.

Right after the election, majority of the Somalis believed that President Farmajo's victory, unlike his predecessors, did not come from intrusive foreign actors and the support from local oligarchies, who ordinarily influenced the political dynamics in Somalia's presidential elections. Almost all Somalis harboured the feeling that the Ethiopian Government backed a different candidate, giving rise to speculations that Farmajo's presidency may actually become hostile to Ethiopia, a regional country with a military presence in Somalia. [5] The fact was, he was not chosen for his famous ardent love of Somaaliweyn-greater Somalia, but it all came following his lauded track record during his premiership in 2010-2011. During this period, he developed a thoughtful reputation in the fight against corrupt and degenerate government officials and provided prompt salaries for the army. Because of his past record, Farmajo became the favourite candidate among his competitors and his election was viewed as a total divorce from the past. Many may have hitherto been led to believe that if Mohamed Abdullahi Farmajo is elected he will implement the same if not better policies he adopted during his premiership. However, accumulative experiences of his two years of presidency signals that Farmajo pursued policies of the exact opposite.

2 Religious narration sermons. 
The other important issue was that President Mohamed Farmajo was not at all like his predecessors, who were either explicitly Islamist politicians or leaning against a certain offshoot school of thought in the Islamic jurisprudence. ${ }^{3}$ Farmajo was a lone ranger, so to speak. For instance, Hassan Sheikh was the follower of Dam-ul-Jadid, a branch of the Al-Islah school of thought, while Sheikh Sharif Sheikh Ahmed was an ardent loyalist to Aala Sheikh, a small branch under the Salafi school of thought. Farmajo restricted factions based on governmental issues and focussed on the proposition of getting rid of the flawed 4.5 Somalia's power-sharing recipe that guaranteed the predominance of the four noteworthy clans. [6]

The February 8, 2017 ballot was one of the most expensive and competitive election processes and a "milestone” [7] according to United Nations officials. Rumours suggested that the candidates spent tens, if not hundreds of thousands of dollars to bribe electoral staff [8] in a bid to win their votes, which damaged the credibility of Somalia's election process once again. The newly-elected senators and members of parliament, largely dominated by youth, seemed impregnated with the feeling of pan-Somali nationalist sentiment, which offset the traditional meddling by regional countries, and thus shifted the 2017 presidential selection paradigm in Somalia. Farmajo received strong support from the diaspora's youngsters, who applied their media savvy skills in managing his political campaign with patriotic zeal centred on pan-Somali nationalism and anti-Ethiopian involvement in the Somali national affairs. The call of nationalism sent crystal clear messages to the emissaries of Addis Ababa to keep their hands-off Somalia. In the election, nearly $44 \%$ of the Members of Parliament (Lower House) and Senators (Upper House) were from the diaspora and holders of dualcitizenship. Approximately 45\% of them were youth between the ages of 25-37. [9] Saturated with the then decades-old pan-Somali nationalistic emotions, these young lawmakers, who have lived most of their life abroad expedited President Farmajo's diplomatic cold shoulder approach towards the Ethiopian Government. However, in the aftermath of the election, although his administration emphasised messages of goodwill and reassurances to these countries in the Horn of Africa region, they could not assuage Ethiopia's fear of the unknown as a result of Farmajo's populist nationalist campaign rhetoric will shape his leadership style. Nonetheless, the government in Addis Ababa attempted to downplay the regional centres of power, thus, they were obliged to "wait and see" as to which direction would move President Farmajo's frail government. The heretical Somali politicians reprimanded Somalia's President, owing to his obsession with pan-Somali nationalism fearing that it would be an untimely spoiler to the fragile Ethiopian-Somali relationships as well as with other regional actors. In so doing, they felt that nothing would stop the new president from being diplomatic in handling the already precarious political situation of Somalia. Even though some of the regional political analysists depicted his extraordinary cognizance of pan-Somalism ideals as dangerous, as holding a "sharp blade" towards his ribs. However, contrary to that, the new Federal Republic of Somalia's youthful lawmakers saw Farmajo's presidential triumph as recapturing Somalia's sovereign identity.

The major Sunni school of thoughts, i.e. madhhabs in the Islamic jurisprudence are Hanafi, Maliki, Shafi and Hanbali. They emerged in the ninth and tenth centuries CE and by the twelfth century almost all jurists aligned themselves with a particular madhhab. 
Besides participating in the African Union Mission to Somalia (AMISOM), Ethiopia has an additional military presence on the basis of a bilateral agreement with successive Mogadishu governments. There were no sources of reliable information regarding the exact number of deployed Ethiopian armies, however, the magnitude seemed adjustable depending on the level of the threat perceived by Ethiopia. Addis Ababa's mounting scepticism concerning the continuity of the past style of diplomatic relations with Somalia took a nosedive when Farmajo won the 2017 election with an overwhelming victory over the preferred candidate, Hassan Sheikh Mohamud. What is more, former PM Farmajo expressed concern over the unconcealed support that the Ethiopian Government rendered to the incumbent president during the election. While Ethiopia backed the re-election of Hassan Sheikh Mohamud other foreign actors with a vested interest in Somalia supported different candidates. For instance, the Emirate chiefdoms and Kenya both threw their support behind the incumbent Prime Minister, Abdirashid Sharmarke. Addis Ababa's emissary presence in the polling Hall on the Election Day completely and virtually infuriated everyone (Somali) and more so the young Somali parliamentarian. Past allegations against Ethiopia on hawking Somalia's affairs gained ground and the sentiments that followed pivoted the redirection of the ballots in favour of the hardly expected presidential candidate, the former Prime Minister of Somalia. Consequently, the resulting opaque diplomatic relations between Ethiopia and Somalia were attributed to the presidential election that saw not only a change of leadership, but also a change in the status quo, as well as the transformation to the existing state of Mogadishu's foreign policy strategy.

Farmajo's first official foreign trip did not begin in Ethiopia, unlike his antecedent presidents.

Despite the fact that this move has pulled in numerous Somali individuals at home and abroad and was broadly discussed by numerous Somali analysists, President Farmajo was seen as having nothing to do with his Ethiopian neighbour. Anyway, Somali elites assumed that the president ought not to ignore the influence of the Ethiopian Government on Somalia's permeable security circumstances nor her regional hegemonic role in ensuring the security of his administration under the flagship of AMISOM. Numerous Somalis nurtured the possibility that the new president would make a fresh start to reconstruct the Federal Republic of Somalia's foreign policy options, if he seeks to formalise relationships with regional powers.

Nevertheless, the former Ethiopian Minister Mr Hailemariam Desalegn explicitly responded to the Somali allegation about Ethiopia's alleged intrusion into Somalia's affairs: "Without the approval of the Somali Federal Government, Ethiopia and any other country, they should not interfere with the independence and sovereignty of Somalia. I think this is clear. As a person I cannot accept that this country is directly involved in the affairs of my country without my permission, and in Somalia like that” [10]—said the prime minister of Ethiopia.

In an attempt to shore up the diplomatically waning relationship with Ethiopia, President Farmajo's government considered a pre-emptive step by including Yusuf Garad Omar as the Foreign Minister in the cabinet. Yusuf Garad was the BBC's Somali-dialect correspondent, and a long-time dissenter to Ethiopia's intervention in Somalia particularly in 2006. Minister Omar continually suffered the allegations of abetting the Islamic Courts Union (ICU) led by Sheik Hassan Dahir Aweys with whom he shares a direct ancestry 
A. [S.] Ahmed ABDI: President Farmajo’s Election: A Brief Hiatus or Hype in Ethiopia’s Regional...

linkage. Such political gestures have transmitted an explicit message to Ethiopia that Somalia is committed to open a new page of frail relations with her neighbour. The regime in Addis Ababa expressed subtle worries about the dynamics of the Somali public opinion and the emerging populist politicians ever since the end of the 2017 Somali general election. The growing populist-nationalist politicians in Mogadishu and the youngsters dominated Somalia's August Houses (Senators and MPs) raised concerns about Ethiopia's hegemonic ambitions in Somalia. Such concerns accelerated the Ethiopian Prime Minister's reflective remarks in favour of the incumbent Somalia President Hassan Sheikh Mohamed in an interview he gave to Universal Television, the Somali language TV channel based abroad. [11] The pertinent observation made by Ethiopian PM was an attempt to influence voters of whom the majority considered President Hassan Sheikh an Ethiopian marionette. The PM's weighty comments sent an explicit message to the Somali public that the regime in Addis Ababa is content with Hassan Sheikh Mohamud's government and highlighted its commitment to back him in the 2017 presidential race. However, the Mogadishu populist politicians saw Ethiopia's pledge for Hassan Sheikh's re-election as one that poses riddles to Somalia's sovereignty and the supremacy of their future presidential choice. Whatever one's attitude towards President Farmajo's election, it cannot be denied that the first quarter of his leadership has provided an ideal opportunity to scupper the talks of Ethiopian de facto hegemonic dividends in the Horn region.

On the other side, the prevailing political situation in Ethiopia and budding circumstances led the youth in the Oromia region to demonstrate against the Ethiopian People's Revolutionary Democratic Front (EPRDF) regime in a push to weaken the federal government and reduce her regional affairs involvement. In turn this provided an opportunity to revitalise the pan-Somali riddle. As a result, Somali populist intellectuals in Mogadishu interpreted the event happening in Ethiopia as a withering of authority of the EPRDF Government, which they believed would automatically divert attention away from Somalia to internal issues.

In January 2017, an independent Ethiopia-based Centre for Dialogue and Research and Cooperation (CDRC) monthly publication analysed the forthcoming Somalia elections scheduled for 8 February 2017. The CDRC think-tank and self-anointed devotee to the study of political and economic integration in the Horn of Africa region issued an opinionated discourse that polarised regional stakeholders. [12] The CDRC argued that by enabling Somali clans (Darood tribe) other than Hawiye to win Somalia's presidential seat, this could permit international extremist groups, for example, Al-Shabaab to make Mogadishu a playing field which would make it impossible for government activities to operate in the capital, Mogadishu. [13] This article coincided with the interview the former Ethiopian PM had given to Universal TV favouring endorsement to the incumbent President Hassan Sheikh Mohamud from the Hawiye clan. But one thing the CDRC Digest forgot to include in their January-February Special Issue was the fact that Somalia's politics did not follow convention. Somalia's political culture is determined by pride, which influences its course resulting in the marked changes in the system, fashion, or appearance.

Thus, ethnonationalism partly entangled with irredentist quests superseded the reconstruction narrative of the Ethiopian-Somali good relations under President Hassan Sheikh. In view of the remarkable foreign stakeholders involved in the already polarised presidential election in 2017 in Somalia and the web of the conflicting interests on the 
horizon, one would suggest that the Addis Ababa regime made a rash decision to unveil her staunch resolution to back the former President Hassan Sheikh. Perhaps these and other compounded factors including the populist-nationalist sentiments directed towards Ethiopia form a point of reference for the soaring instability of the relations between President Farmajo's government and the Addis Ababa regime. In the recent past, foreign actors expressed interest in Somalia's political affairs. Their meddling increases today more than ever before. Turkey's commitment to Somalia is one example among many of the rising actors in Somalia. Turkey's buy-in model of commitment is demonstrated by the speedy delivery of support projects on the ground using a Turkish workforce to regulate maximum use, which emphasises soft power attributes such as business interests and cultural affinity such as Turkey's Muslim identity. Such attitudes are dissimilar to Somalia's customary donors who are frequently blamed for being excessively bureaucratic, moderate and disengaged, either bunkered in the aeroplane terminal in Mogadishu or giving aid remotely from neighbouring nations. [14]

Since the collapse of state institutions in 1991, Somalia became a site of proxy wars among Ethiopia, Kenya, Eritrea and Djibouti. Diverse international actors backed them, all of whom have vested interests, and at times, have aligned themselves with various Somali clans, regional states administrations, or political alliances in order to subvert a rival or gain access to unprotected inland and island resources. Somalia is strategically important to all foreign actors for various reasons including securing shipping routes in the Bab al Mandab Strait, proximity to the ongoing conflict in Yemen, and the desire to avail forces in the region alongside rivals including the United States and Russia. [15] The rivalry race between the United Arab Emirates (UAE) and Turkey in the Horn of Africa has yielded blended outcomes in Somalia. Both countries have in the past injected monetary and material support into Somalia to establish their own institutions to pawn and combat Al-Shabab terrorist group threats. On top of that Turkey has exceeded expectations in terms of humanitarian aid. The Turkish aid model has fascinated Somalis in the private-public domain and the politicians, consequently receiving the highest profile intervention in Somalia, making Somalia one of the top five largest recipients of official aid from Turkey since 2011. [16] The Federal Government of Somalia (SFG) has received huge counterterrorism support from the two countries, and compassionate aid support from Turkey.

Although both countries have shared a heritage, (Islamic faith) with Somalia, their competition has of late stressed relations between the Federal Government of Somalia and Somalia's semi-autonomous regional states administrations. Recently the Dubai Ports World's (DPW) ambitious search for a strategic partnership between the Dubai Ports World conglomerate and the breakaway northern district of Somaliland led to the promise of a total pledge of \$440 million to recreate the Berbera seaport. While Turkish organisations reportedly operated in the Mogadishu seaport ever since 2014, other Turkish organisations have been seen building streets, schools and healing centres (hospitals). Recent speculations indicate that Turkey, an ally of Qatar, is sanctioning a multi-billion-dollar investment in Somalia. [17] President Mohammed Abdullahi Farmajo rejected the authenticity of a 30-year United Arab Emirates contract on the port of Berbera in Somaliland. [18] This was a crucial moment, which hinted to the Chiefdoms of the United Arab Emirates that Somalia is fed up with being put down and made to feel stupid. The president explicitly shared his country's unwillingness to engage in future commitments with the Emirates. 
Formerly UAE Emirati military manoeuvres in Yemen depended heavily on their base in Djibouti. Since March 2015, it was acknowledged that Emirati Chiefdoms have been part and parcel of the Saudi-led coalition that initiated the war against the Houthi rebel forces in Yemen. However, what still remains uncertain is the central impetus that led UAE to become immersed in the Yemeni war, other than merely tiptoeing into the narrative of the Gulf Council Countries solidarity. [19] The UAE’s phenomenal move towards prioritsing ports in Eritrea in 2015, a longtime rival to Djibouti has caused tensions with the latter. This and the diplomatic clash between the UAE emissaries and Djibouti's head of Aviation Armed forces over the modalities of the Djibouti port rental contract expedited Djibouti's move to hastily rescind the agreement with Dubai's DP World [20] that existed for two decades. A fight for access to seaports was going on along Somalia's stretched strategic seashore. Somalia now got up to speed in a territorial battle between Saudi Arabia and the Bedouin Emirates (UAE) on one side, with Qatar supported by Turkey on the other, all in pursuit of vested interest, mainly to control the strategic seaports in Somalia.

\section{Political Reforms and Rapprochements: A New Lexicon for the Horn Region}

President Mohamed Abdullah Farmajo's selection coincided with the peak of political upheaval in Ethiopia. Since 2016 the Ethiopian Government experienced public protests of dissatisfaction with the EPRDF led government in Ethiopia. Among the major issues that triggered these protests included the controversial government plan to amalgamate eight towns in the Oromia Special Zone with Addis Ababa. [21]

This was occasioned through the leadership change that occurred in Ethiopia which brought PM Abiy Ahmed Ali to office since the $2^{\text {nd }}$ of April 2018. [22] The unprecedented change in leadership that occurred in Ethiopia undoubtedly gave a new hope that enabled the Farmajo Government to imagine a new Ethiopian government, which would sustain weak central power and would improve marred Ethiopian-Somali diplomatic coordination. Upon taking the oath of office as Prime Minister, Dr Ahmed shut all windows, both internal and external that would likely cause harmful political and diplomatic consequences for his government. As luck would have it, his first step was to defrost the risky arch-foe relations of Ethiopia-Eritrea. Internally, he embarked on the journey to peace. Armed groups formerly supported by Eritrea, the Ogaden National Liberation Front (ONLF), Oromo Liberation Front (OLF), Patriotic Ginbot Sebat (PG7) and Tigray People’s Democratic Movement (TPDM) all entered into peace agreements with Dr Abiy Ahmed's government. ONLF, OLF and PG7 were all removed from the Ethiopian Government's list of “terrorist” organisations.

In August and September 2018, the Government of Eritrea hosted and facilitated peace negotiations between the Government of Ethiopia and ONLF, OLF and TPDM. [23] Ever since the start of the Ethiopia-Eritrea war in 2000, Ethiopia and her archfoe enemy, Eritrea both embarked on a proxy war on Somali soil. Occasionally, Ethiopia was accused of meddling in the Federal Republic of Somalia's affairs only to institute a weakling government under its foreign policy surveillance, one in the interim, as well as the postinterim successive government in Mogadishu. By the same token, Ethiopia was suspected of allegedly taking sides in among opposition factions in Mogadishu. Conversely, Eritrea, 
regularly mentioned in the UN Arms Monitoring reports, backed the Islamic militants (read Al-Shabaab), which were excessively engaged in fierce fighting intent on overthrowing the government in Mogadishu, a charge it has always denied.

Reports pointed a finger at Eritrea for covertly providing support in cash and kind to armed groups, mainly the Al-Qaeda linked Al-Shabaab militants and other destabilising forces who obliviously undermined the glowing light of stability emerging from Somalia. In addition, the Security Council reported that Eritrea refused to pull back its occupying forces following conflicts with Djibouti in June 2008. Following this in 2009, the United Nations Security Council imposed an arms embargo and targeted sanctions on Eritrea, in addition to travel restrictions on its political and military leaders [24] as well as freezing their assets. In the wake of Ethiopia's rapprochement efforts with Eritrea that was initiated under the lightning reforms under the new Prime Minister Abiy Ahmed, President Mohamed Abdullah Farmajo formed closer ties with Ethiopia's new reformist leadership. Together they began to forge a new chapter based on an improved relationship, one that supported the political independence, sovereignty, and territorial integrity of their respective countries through friendly political, economic, social, cultural as well as defence and security cooperation between the two countries. [25]

\section{Conclusion}

President Farmajo's abstract nationalist mythmaking geared towards Ethiopia during his campaign has been eclipsed by the conceptual realities he later found on the ground. The Ethiopian influence towards the Federal Republic of Somalia was beyond public perception.

One will ask whether an estimate of nearly five thousand Ethiopian troops officially present in Somalia under the auspices of the African Union Mission in Somalia (AMISOM), and the same number of troops if not more are still present within Somalia territory under the pseudo-deal of a 'bilateral agreement' with the preceding Somalia governments? If so, then to what extent can President Farmajo's nationalist rhetoric against Ethiopia be proven? Has his talk of irredentism been implemented in practice in the post-election era?

Conversely, the hard task awaiting President Farmajo's government is to strategise how to synchronise the shifting premises of his campaign propaganda from enmity to unprecedented political and diplomatic amity towards Ethiopia. Generally, the Somali public has always been cynical and any signs of a political turn towards forging closer diplomatic ties with Ethiopia under President Farmajo's reign would be considered with denigration and most likely may lead to charges of betrayal. On June 16, 2018 Ethiopia PM Abiy Ahmed visited Mogadishu to initiate an act ending the history of war and violence between the two nations. Prime Minister Abiy said his vision included: "A common trade area where people, ideas, goods and products move freely across borders. It is a future where we work to enlarge opportunities for our people and work for economic security that gives our children and grandchildren great hope.” [26] However, sceptical Somalis greeted the initiative with a high degree of political reservation. It also created a negative impression resulting in a new discourse denting President Farmajo's trust and political credibility among the Somali nationalists and other elites. This expedited the mouldings of a new charge against President Farmajo for allegedly signing a dubious agreement with Ethiopia's 
PM that would let freely Somalia's seaports to Ethiopia. In order to face these immense challenges, Farmajo needs to create a committed bilateral front. Although he seems to be sensitive to the necessity of forging an unconditionally closer political partnership with the government in Addis Ababa, he may fear losing popular support from the predominantly youth and diaspora parliamentarians as well as the larger Somali public. President Mohamed kept his voice distant and instead maintained a mildly curious behaviour towards forging closer ties with Ethiopia instead crying for an alternative partnership. [27]

Conversely, pan-Somali nationalist politicians believed that an Ethiopian presence in Somalia is not only part of the African peacekeeping mission to Somalia. They considered that Ethiopia has another agenda to suppress Somalis' inherent irredentist sentiment and encourage the creation of a genuinely malleable kind of government in Somalia that will never be a threat to her self-designated hegemonic role in the region. Thus, President Farmajo before smoothing relations with Ethiopia must put a roadmap in place to see Ethiopian troops off Somali soil so as to cool down anti-Ethiopian feelings expressed by the public in Somalia, otherwise he may not survive to uphold the same political credibility he gained during his campaign.

PM Abiy Ahmed Ali upon coming to power in April 2018, issued speedy reforms, one of which had a tremendous impact on Somalia's securitisation efforts, namely ending the decades-long border dispute with Eritrea, which has cost thousands of lives from both sides. This move helped the Federal Republic of Somalia to escape from being fertile ground for the Ethiopia-Eritrea intermediary war.

The unprecedented geopolitical changes occurring in the Horn region have also radically reshaped the Ethiopian-Somali relationship. The neo-Ethiopia under PM Abiy Ahmed appears to be disinterested in diving deep into Somalia's internal affairs, a gesture that could bring President Farmajo’s government closer in relationship.

The political deadlock between President Mohamed Abdullah Farmajo and the federal member states, who have been vocal in demanding a more voluntarily autonomous relationship, (a kind of confederation of states) with Mogadishu continues. Somalia's federal regional states occasionally reproach President Farmajo's insatiable quest to create an autocratic central government that disobeys the establishment of the 2012 Provisional Constitution that shifted Somalia into federalism. The unlawful manipulation of the south west regional state presidential elections in Baidao following the arrest of the leading contender using Ethiopian troops on the $15^{\text {th }}$ of December 2018 proved federal states leaders right. This action propelled them into a state of further anxiety and mistrust of President Farmajo’s Mogadishu regime. President Farmajo obviously wanted to use the same tactic to manipulate Jubaland's election. The operation seemed to have been aborted when the state airport in Kismayu town, Jubaland vehemently denied an Ethiopian plane to land on Monday 19 August 2019. According to the Jubaland administration, the plane allegedly carried Ethiopian commandos, who could manipulate by force the election scheduled for Thursday 22 August 2019. President Mohamed Abdullah Farmajo not only swerved away from his policy objectives of capitalising on the securitisation of the country, but also abandoned his nationalist slogans of anti-Ethiopia rhetoric, par excellence that transcended Farmajo as the winner of the 2017 federal Somalia's presidential election.

A burning question remains: will the neo-Ethiopia regime discontinue its serious involvement in Somalia's affairs for ever or is it only taking a temporary pause for now up 
A. [S.] Ahmed ABDI: President Farmajo’s Election: A Brief Hiatus or Hype in Ethiopia’s Regional...

until it stabilises its internal crisis? Only time will tell. The majority of the Somali elites criticised Mohamed Farmajo's stance on the much publicized "Horn of Africa economic integration agreement” led by Ethiopian PM Abiy Ahmed Ali as an act against Somalia's long-standing political dispute towards Ethiopia. They further added that the move is likely to damage and devalue the political character of President Farmajo. It seems as though President Mohamed Farmajo is not prepared to second guess, whether the new political reforms in Addis Ababa herald a re-definition of her past foreign policy towards the hegemonic ambition of the Horn of Africa region.

\section{References}

[1] How Regional State Presidents Are Used in Campaign Machinery by Presidential Candidates. Radio Dalsan, 07.02.2017. www.radiodalsan.com/en/2017/02/07/how-regionalstate-presidents-are-used-in-campaign-machinery-by-presidential-candidates (Downloaded: 06.08.2018)

[2] RHYMER, S.: The Reluctant Imperialist: Italian Colonization in Somalia. Trenton, World Press, 2011.

[3] AYOOB, M.: The Horn of Africa Regional Conflict and Super Power Involvement. Canberra, Australian National University, 1978.

[4] SHEILA, R.: Somalia and Ethiopia Resume Relations. The New York Times, 05.04.1988. www.nytimes.com/1988/04/05/world/somalia-and-ethiopia-resume-relations.html (Downloaded: 06.09.2018)

[5] OKELLO, C.: The World and All Its Voices. RFI, 03.03.2017. http://en.rfi.fr/ africa/20170502-somalia-eyes-new-chapter-ethiopia-ties (Downloaded: 11.04.2018)

[6] MUSHTAQ, N.: Somalia under Farmaajo: Fresh start or another false dawn? Nairobi: Life \& Peace Institute, 2017. http://life-peace.org/hab/somalia-under-farmaajo-fresh-start-oranother-false-dawn/ (Downloaded: 06.09.2018)

[7] GETTLEMAN, J.: Fueled by Bribes, Somalia’s Election Seen as Milestone of Corruption. The New York Times, 07.02.2017. www.nytimes.com/2017/02/07/world/africa/somaliaelection-corruption.html (Downloaded: 12.04.2018)

[8] MARSAI, V.: Somali elections in 2016-2017.-Business as usual or a new hope? Center for Strategic and Defense Studies, 14 (2017). www.researchgate.net/publication/319313837_ Somali_elections_in_2016-2017_-_Business_as_usual_or_a_new_hope (Downloaded: 12.04.2018)

[9] SHEIKH, A.: An Open Letter to Somalia President Mohamed Abdullahi. Aigaforum.com, 23.04.2017. http://aigaforum.com/article2017/an-open-letter-to-somalia-president.htm (Downloaded: 12.04.2018)

[10] Itoobiya: Madaxbannaanida iyo qarannimada Soomaaliya ma faragelineyno. BBC News, 05.03.2017. www.bbc.com/somali/war-39823765 (Downloaded: 06.12.2018)

[11] Desalegn, Hailemariam, interview by Universal TV. The Horn of Africa Politics and Somalia's Issues of Unity, 04.02.2017.

[12] SHIRE, M.: Somali Elections and the External Interferences. All East Africa, 28.01.2017. www.alleastafrica.com/2017/01/28/opinion-somali-elections-and-the-external-interferences/ (Downloaded: 06.14.2018) 
A. [S.] Ahmed ABDI: President Farmajo’s Election: A Brief Hiatus or Hype in Ethiopia’s Regional...

[13] The commotion surrounding Somalia's transition. (Study report) Addis Ababa, Centre for Dialogue, Research and Cooperation, 2017.

[14] CONING, C. T.: Call and Cedric de. Thinking Outside the Compound: Turkey's Approach to Peacebuilding in Somalia. Cham, Springer Nature, 2017. DOI: https://doi.org/10.1007/9783-319-60621-7_8

[15] SCHWAB, P.: Cold War on the Horn of Africa. African Affairs, 77306 (1978), 6-20. DOI: https://doi.org/10.1093/oxfordjournals.afraf.a096955

[16] ACHILLES, K. - SAZAK, O. - WHEELER, T. - WOODS, A. E.: Turkish aid agencies Risks and opportunities for building peace. Istanbul, Saferworld and Istanbul Policy Center, 2015.

[17] ANALYSIS-Harbouring ambitions: Gulf states scramble for Somalia. Reuters, 02.05.2018. https://af.reuters.com/article/commoditiesNews/idAFL8N1S81NY (Downloaded: 06.17.2018)

[18] KANTACK, J. M.: The New Scramble for Africa. Qaran, 28.02.2018. http://qaranka. com/2EngNew/14.html (Downloaded: 06.16.2018)

[19] NASSER, A.: A double-edged operation for UAE in Gulf of Aden. The New Arab, 13.10.2016. www.alaraby.co.uk/english/comment/2016/10/13/a-double-edged-operation-foruae-in-gulf-of-aden (Downloaded: 06.16.2018)

[20] Djibouti ends Dubai's DP World contract to run container terminal. Reuters, 22.02.2018. www.reuters.com/article/us-djibouti-ports-dp-world/djibouti-ends-dubais-dp-world-contractto-run-container-terminal-idUSKCN1G62HE (Downloaded: 06.16.2018)

[21] BULA, M. Y.: Political unrest simmering in Ethiopia. DW, 10.02.2017. https://p. dw.com/p/2XIzv (Downloaded: 20.12.2018)

[22] CUNNINGHAM, F.: Ethiopia in Turmoil of US, Saudi-Backed Coup, Not 'Reforms'. Strategic Culture Foundation, 20.08.2018. www.strategic-culture.org/news/2018/08/20/ ethiopia-turmoil-of-us-saudi-backed-coup-not-reforms.html (Downloaded: 27.12.2018)

[23] Monitoring Group on Somalia and Eritrea. New York, UN Security Council, 2018.

[24] Security Council Imposes Sanctions on Eritrea over its Role in Somalia, Refusal to Withdraw Troops Following Conflict with Djibouti. Meeting Coverage Report. New York, United Nations, 2009.

[25] Somalia, Eritrea mend ties as change sweeps Horn of Africa. The East African, 30.07.2018. www.theeastafrican.co.ke/news/africa/Somalia-Eritrea-mend-ties-as-change-sweeps-Hornof-Africa/4552902-4688620-vgh73az/index.html (Downloaded: 27.12.2018)

[26] PLAUT, M.: Ethiopian Prime Minister Abiy calls for regional common market during Somali visit. Eritrea Hub, 18.06.2018. https://eritreahub.org/ethiopian-prime-minister-abiycalls-for-regional-common-market-during-somali-visit (Downloaded: 27.12.2018)

[27] Ethiopia Troops Least Popular of AMISOM Peace Keepers in Somalia. Tesfa News, 01.01.2017. www.tesfanews.net/ethiopia-troops-least-popular-amisom-mission-somalia/ (Downloaded: 06.09.2018) 